\title{
Peningkatan Ekspresi Vascular Endothel Growth Factor dan Mitogen Activating Protein Kinase Plasenta Tikus yang Dipapar Carbon Black
}

\author{
((INCREASING EXPRESSION ON VASCULAR ENDOTHELIAL GROWTH \\ FACTOR AND MITOGEN ACTIVATING PROTEIN KINASE \\ IN PLACENTA RATS EXPOSED CARBON BLACK)
}

\author{
Viski Fitri Hendrawan ${ }^{1}$, Widjiati ${ }^{2}$, \\ Suherni Susilowati ${ }^{3}$, Pudji Srianto $^{3}$ \\ ${ }^{1}$ Departemen Reproduksi, Fakultas Kedokteran Hewan, Universitas Brawijaya \\ Jl. MT. Haryono No.169, Malang, Jawa Timur, Indonesia, \\ Telpon : 0341573642, Fax : (0431-551611 PSW 362 \\ Email: viski_hendrawan88@yahoo.com \\ ${ }^{2}$ Departemen Anataomi Veteriner, ${ }^{3}$ Departemen Reproduksi Veteriner, \\ Fakultas Kedokteran, Hewan Universitas Airlangga
}

\begin{abstract}
ABSTRAK
Carbon black merupakan salah satu komponen partikulat matter (PM) yang diketahui bersifat sitotoksik serta menyebabkan terjadinya inflamasi pada sistem pernafasan dan kardiovaskular serta dapat melewati barier plasenta fetus sehingga dapat memengaruhi fetus. Efek yang ditimbulkan oleh polutan tergantung dari besarnya paparan dan lama waktu paparan. Penelitian ini bertujuan untuk mengidentifikasi Vascular Endothel Growth Factor (VEGF) dan Mitogen Activating Protein Kinase (MAPK) sebagai indikator imflamasi pada plasenta maternal tikus (Rattus norvegicus) yang dipapar carbon black dengan teknik immunohistokimia. Penelitian ini dilakukan, dengan tiga kelompok perlakuan dan tujuh kali ulangan yang menggunakan tikus betina bunting. Tikus betina bunting dipapar dengan carbon black dosis $523 \mathrm{mg} / \mathrm{m}^{3}$ dan $1064 \mathrm{mg} / \mathrm{m}^{3}$ selama kebuntingan hari ke-6 sampai 11. Tahap berikutnya adalah pengamatan dan pemeriksaan ekspresi VEGF dan MAPK dengan pewarnaan immunohistokimia terhadap plasenta tikus putih yang telah dipapar dengan carbon black. Hasil penelitian adalah terjadi peningkatan ekspresi VEGF pada plasenta tikus yang dipapar carbon black dosis $523 \mathrm{mg} / \mathrm{m}^{3}$ dan $1064 \mathrm{mg} / \mathrm{m}^{3}$ per inhalasi selama masa pertengahan (6-11) kebuntingan. Selain itu terjadi peningkatan ekspresi MAPK pada plasenta tikus yang dipapar carbon black dosis $523 \mathrm{mg} / \mathrm{m}^{3}$ dan $1064 \mathrm{mg} / \mathrm{m}^{3}$ per inhalasi selama masa pertengahan(6-11) kebuntingan. Simpulan penelitian ini adalah ekspresi VEGF dan MAPK meningkat seiring dengan peningkatan dosis carbon black dan umur kebuntingan.
\end{abstract}

Kata-kata kunci: carbon black;mitogen activating protein kinase; vascular endothel growth factor; tropoblas plasenta.

\begin{abstract}
Carbon black is one of the components of particulate matter (PM), known as cytotoxic, causing inflammation in the respiratory and cardiovascular system, and able to pass through the placental barrier, which may affect the fetus. The effects caused by pollutants depend on the intensity and time length of the exposure. The objective of this study is to identify Vascular endothelial growth factor (VEGF) and mitogen-Activating Protein Kinase (MAPK) as an indicator of maternal placental inflammation in pregnant rats (Rattus norvegicus) exposed to carbon black with immuno-histochemical technique. This study was a laboratory experiment with three treatment groups and seven replications using pregnant female white rats (Rattus norvegicus). Pregnant female rats were exposed to carbon black with a dosage of $523 \mathrm{mg} / \mathrm{m} 3$ and $1064 \mathrm{mg}$ / m3 during pregnancy of day 6 up to day 11 . The next phase was the observation and examination of the expressions of VEGF and MAPK by immunohistochemical staining toward placenta of the white rats exposed to carbon black. The result of the study showed an increase in the expression of VEGF in the
\end{abstract}


placenta of the rats (Rattus Norvegius) exposed to carbon black with a dosage of $523 \mathrm{mg} / \mathrm{m} 3$ and $1064 \mathrm{mg} / \mathrm{m} 3$ per inhale during the mid-period (6-11) of pregnancy. In addition, there was also an increase in the expression of MAPK on the placenta of the rats exposed to carbon black with a dosage of $523 \mathrm{mg} / \mathrm{m} 3$ and $1064 \mathrm{mg} / \mathrm{m} 3$ per inhale during the mid-period (day 6-11) of pregnancy. In conclusion, the expression of VEGF and MAPK are increased along with the increased dosage of carbon black and age of gestation.

Keywords: carbon black,mitogen activating protein kinase, vascular endothel growth factortrophoblast placenta.

\section{PENDAHULUAN}

Perwujudan kualitas lingkungan yang sehat merupakan bagian pokok di bidang kesehatan. Udara sebagai komponen lingkungan yang penting dalam kehidupan perlu dijaga dan ditingkatkan kualitasnya sehingga dapat memberikan daya dukung bagi mahluk hidup untuk hidup secara optimal. Pencemaran udara dewasa ini semakin menampakkan kondisi yang sangat memprihatinkan. Sumber pencemaran udara dapat berasal dari berbagai kegiatan antara lain industri, transportasi, dan perumahan. Berbagai kegiatan tersebut memberi sumbangan besar terhadap pencemaran udara. Sumber pencemaran udara juga dapat disebabkan oleh berbagai kegiatan alam, seperti kebakaran hutan, gunung meletus, dan gas alam beracun. Dampak dari pencemaran udara tersebut menyebabkan penurunan kualitas udara, yang berdampak negatif terhadap kesehatan manusia. Belakangan ini tumbuh keprihatinan akan efek dari emisi polusi udara dalam konteks global yang dapat mengakibatkan pencemaran udara.

Pencemaran udara dibedakan menjadi dua yaitu, pencemaran secara primer dan pencemaran secara sekunder. Pencemaran primer adalah substansi pencemaran yang ditimbulkan langsung dari sumber pencemaran udara. Karbon monoksida merupakan salah satu contoh dari pencemar udara primer, karena merupakan hasil dari pembakaran yang dapat menyebabkan polusi udara dan memiliki efek negatif bagi kesehatan. Pencemaran sekunder adalah substansi pencemar yang terbentuk dari reaksi pencemaran primer di atmosfer.

Polusi udara yang berasal dari berbagai sumber, dapat berbentuk partikel debu, gas, timah hitam, dan hasil pembakaran yang disebut partikulat matter (PM). Komponen PM merupakan komponen penting yang memengaruhi kesehatan tubuh. Komponen PM sebagian besar memiliki aktivitas mutagenik, dan umumnya terkandung dalam partikel halus (Debojyoti, 2010).

Carbon black merupakan bagian dari PM yang mengadung unsur karbon. Carbon black adalah salah satu produk kimia yang paling stabil di udara. Secara umum, carbon black merupakan nanomaterial yang paling banyak digunakan dan ukuran agregat dimensi carbon black berkisar dari puluhan hingga beberapa ratus nanometer (Jefrey dan Edison, 2013). Carbon black termasuk dalam komponen PM yang bersifat sitotoksik dan genotoksik. Partikulat Matter yang mampu melewati barrier plasenta akan mengakibatkan peningkatan intra uterine growth retredation (IUGR) (Dejmek, 2013).

Carbon black diketahui dapat berpengaruh terhadap fetus melalui beberapa mekanisme di antaranya secara langsung masuk kedalam plasenta, sehingga menyebabkan perubahan fungsi pada plasenta dan secara tidak langsung memengaruhi perubahan sitokin yang ada di plasenta (Hougraad et al., 2011).

Perubahan sitokin pada plasenta akan memengaruhi respons selular yang diakibatkan oleh stres paparan carbon black. Kondisi tersebut akan berkontribusi terhadap peradangan dan gangguan jaringan homeostasis, yang secara berkesinambungan akan berpengaruhi terhadap sistem pembuluh darah di plasenta. Sel pembuluh darah endotel yang ada sepanjang saluran pembuluh darah dalam plasenta akan mengalami gangguan. Akibat terjadinya peradangan, sitokin yang ada akan berkontribusi terhadap proses patologi seperti angiogenesis, vaskular homeostasis dan iskhemia (Monique, 2001).

Menurut Jakcson (2011), Vascular Endothel Growth Factor (VEGF) berperan sangat penting pada diferensiasi sel endotel (vasculogenesis) dan angiogenesis selama perkembangan embrio. Apabila terjadi imflamasi selama proses kehamilan, akan terjadi perubahan ekpresi VEGF dan memengaruhi ekspresi sitokin lain 
yang ada pada sistem vaskuler. Perubahan ekspresi VEGF menyebabkan proliferasi sel endotel dan peningkatan kadar prostaglandin yang selanjutnya akan meningkatkan permeabilitas pembuluh darah.

Vascular Endothel Growth Factor termasuk golongan angiogenik sitokin berfungsi sebagai faktor kelangsungan hidup untuk sel endotel secara in vivo dan in vitro. Vascular Endothel Growth Factor bekerja mengikat reseptor tirosin kinase melalui jalur phosphoinositide 3-kinase (PI 3-kinase)/Akt, akibatnya akan mengaktifkan MAPK. Peningkatan MAPK akan menyebabkan gangguan pada plasenta sehingga akan menyebabkan kelainan kehamilan (Jakcson, 2011). Oleh karena itu penting untuk diketahui peran perubahan VEGF dan MAPK akibat paparan carbon black selama kebuntingan. Penelitian ini bertujuan untuk mengidentifikasi VEGF dan MAPK sebagai indikator imflamasi pada plasenta maternal tikus yang dipapar carbon black dengan teknik immunohistokimia.

\section{METODE PENELITIAN}

Penelitian ini bersifat laboratorik eksperimental dengan alasan semua populasi sama dan memiliki kriteria yang homogen serta karakteristik sama. Pengukuran awal tak dilakukan karena asumsi semua kelompok berasal dari satu populasi dan objek yang diteliti adalah plasenta yang harus mengorbankan nyawa hewan coba terlebih dulu sebelum dilakukan koleksi plasenta. Penelitian ini menggunakan rancangan the post test only control group design.

Sampel yang digunakan dalam penelitian ini adalah tikus betina bunting sebanyak 21 ekor dengan rincian tujuh ekor tikus pada masingmasing kelompok. Sebanyak tiga kelompok perlakuasn, terdiri dari : II K0 : Kelompok kontrol tikus bunting tanpa paparan carbon black, II K1: Kelompok perlakuan tikus bunting yang dipapar. Variabel yang diamati dalam penelitian ini yaitu melihat ekspresi VEGF dengan MAPK.

\section{Pengawinan Tikus}

Tikus disuntik dengan pregnant mare serum gonadotropin (PMSG) dengan dosis 10 IU/ekor, 48 jam kemudian disuntik kembali dengan human chorionic gonadotropin (HCG) dengan 10/ekorIU. Setelah mencit betina disuntik dengan HCG langsung dikawinkan dengan tikus jantan, dengan satu tikus jantan dalam satu kandang. Tujuh belas jam kemudian setelah tikus dikawinkan diperiksa adanya sumbat vagina (vaginal plug). Apabila terdapat sumbat vagina maka dipastikan telah terjadi kopulasi dan pada saat itu dianggap kebuntingan hari ke nol. Sumbat vagina terdiri dari gelatin yang sudah menggumpal dan berfungsi agar spermatozoa tidak tumpah keluar.

\section{Pemberian Paparan Carbon Black Powder}

Carbon black powder yang digunakan sebagai paparan, disemprotkan kedalam udara boks paparan. Perlakuan diberikan dalam boks paparan yang berbeda. Boks tersebut dilengkapi dengan monitor suhu udara, kecepatan aliran udara 5,0 -7,5 km/jam (angin sepoi-sepoi) pada suhu dan kelembaban setempat, dengan tekanan satu atmosfer secara inhalasi. Perlakuan diberikan secara bertahap sesuai dengan kelompok. Hewan coba ditempatkan dalam kandang pemeliharaan sampai perlakuan dimulai. Sebelum percobaan, dilakukan aklimatisasi pada boks paparan. Hewan coba dimasukan kedalam boks paparan untuk diberikan paparan carbon black, dan diberikan sesuai dengan dosis dan waktu masing-masing kelompok perlakuan. Kelompok kontrol diperlakukan sama seperti kelompok perlakuan yaitu dimasukan ke dalam boks paparan dengan lama waktu yang sama tetapi tidak diberi paparan carbon black (Dachlan et al., 2011).

\section{Pembedahan Hewan Coba}

Pembedahan dimulai dengan mengorbankan nyawa hewan coba dengan cara dislokasio os cervicalis. Tikus tersebut didesinfeksi dengan alkohol $70 \%$ pada bagian abdomen kemudian dilakukan pembedahan dengan cepat untuk mengambil uterus. Pembedahan dimulai dari vagina menuju ke arah perut menggunakan gunting kecil, dan uterus difiksasi untuk mengeluarkan fetus. Jaringan plasenta dipisahkan dari uterus tikus, kemudian plasenta disimpan dalam formalin untuk pembuatan praparat immunohistokimia dan pemeriksaan histopatologis.

\section{Identifikasi Ekspresi VEGF dan MAPK dengan Metode Immunohistokimia \\ Prosedur pemeriksaan ekpresi VEGF dan MAPK melalui tahapan yaitu membuat}


potongan preparat plasenta pada gelas objek, yang kemudian direndam dalam xylol sebanyak dua kali dan alkohol bertingkat (100\%, 90\%, 80\%, $70 \%$, dan 30\%). Untuk menghilangkan sisa xylol dan alkohol yang berisi sisa jaringan plasenta selanjutnya gelas objek dicuci dengan aquades. Gelas objek yang berisi jaringan plasenta selanjutnya dicuci dengan PBS pH 7,4 sebanyak tiga kali, masing-masing selama lima menit, kemudian direndam dengan hidrogen peroksidase $\left(\mathrm{H}_{2} \mathrm{O}_{2}\right) 3 \%$ selama 5-10 menit. Proses berikutnya adalah merendam gelas objek yang berisi jaringan plasenta dengan 1\% BSA dalam PBS selama 10-30 menit dan dibiarkan pada suhu ruang. Kemudian memasuki tahapan berikutnya yaitu coating dengan antibodi primer VEGF dengan cara merendam gelas objek yang berisi jaringan plasenta dengan antibodi primer VEGF selama satu jam pada suhu ruang. Selanjutnya untuk menghilangkan sisa antibodi primer dilakukan dengan menambahkan PBS $\mathrm{pH}$ 7,4 dan mendiamkan selama 3x5 menit. Tahapan selanjutnya menambahkan Strep Avidin-Horse Radish Peroksidase (SA-HRP) selama 30-60 menit pada suhu ruang dan PBS $\mathrm{pH} 7,4$ selama $3 \times 5$ menit. Agar antigen dan antibodi primer bisa terikat dengan sempurna maka ditambahkan Cromogen $\operatorname{DAB}(3,3$ diaminbenzidine tetrahydrochloride) selama 1020 menit. Selanjutnya sisa cromogen dibersihkan dengan merendam dalam aquadest selama 3x5 menit, selanjutnya ditambahkan dengan counterstain commasie blue agar sel tropoblas yang mengekspresikan VEGF dan MAPK serta yang tidak mengekspresikan VEGF dan MAPK bisa terlihat kontras. Pengamatan dilakukan menggunakan mikroskop dengan pembesaran 1000 kali.

Secara prinsip tahapan pemeriksaan ekpresi VEGF dan MAPK adalah sama. Yang berbeda adalah saat melakukan coating antibodi. Pemeriksaan ekpresi MAPK maka saat melakukan coating antibodi primer dengan cara menambahkan antibodi primer MAPK.

\section{Analisis data}

Ekspresi VEGF dan MAPK pada setiap sampel dinilai secara semikuantitatif menurut metode Remmele yang sudah dimodifikasi (Novak et al., 2007). Indeks skala Remmele (IRS) merupakan hasil perkalian antara skor persentase sel immunoreaktif dengan skor intensitas warna yang dihasilkan pada sel seperti pada Tabel 1.

Data yang didapat dianalisis secara deskriptif maupun analitik. Analisis deskriptif menggunakan kompilasi dan tabulasi data yang disajikan dalam bentuk tabel distribusi dan frekuensi masing-masing variabel. Analisis data dilakukan dengan menggunakan analisis varian satu arah. Analisis dilakukan dengan asumsi populasi yang diuji berdistribusi normal, homogen, dan sampel tidak berhubungan satu sama lain.

\section{HASIL DAN PEMBAHASAN}

\section{Ekspresi VEGF pada Placsenta Tikus Bunting yang Dipapar Carbon Black}

Pengaruh paparan carbon black terhadap ekspresi VEGF plasenta melalui pewarnaan imunohistokimia berdasarkan umur kebuntingan dan dosis paparan, dihitung secara semikuantitatif, disajikan pada Tabel 2, 3, dan Gambar 1.

Dari hasil analisis statistika didapatkan perbandingan terhadap waktu kebuntingan yang sama antara kelompok tanpa paparan carbon black pada umur kebuntingan 6-11 hari selama delapan jam (II-KO) dengan kelompok perlakuan dengan paparan carbon black pada umur kebuntingan 6-11 hari selama delapan jam dengan dosis $534 \mathrm{mg} / \mathrm{m}^{3}$ (II-KI) dengan

Tabel 1. Skala semikuantitatif indeks skala Remele (IRS) merupakan hasil perkalian antara skor persentase sel positif (A) dengan skor intesitas reaksi warna (B), jadi skala IRS = ( A x B)

\begin{tabular}{ll}
\hline A (Skor persentase sel positif) & B (Skor intensitas reaksi warna) \\
\hline Skor 0 : tidak ada sel positif & Skor $0:$ tidak ada reaksi warna \\
Skor 1 : Sel positif kurang dari $10 \%$ & Skor $1:$ Intensitas warna rendah \\
Skor 2 : Sel positif antara dari $11 \%-50 \%$ & Skor $2:$ Intensitas warna sedang \\
Skor $3:$ Sel positif antara dari $51 \%-80 \%$ & Skor $3:$ Intensitas warna kuat \\
Skor $4:$ Sel positif antara dari lebih dari $80 \%$ & \\
\hline
\end{tabular}




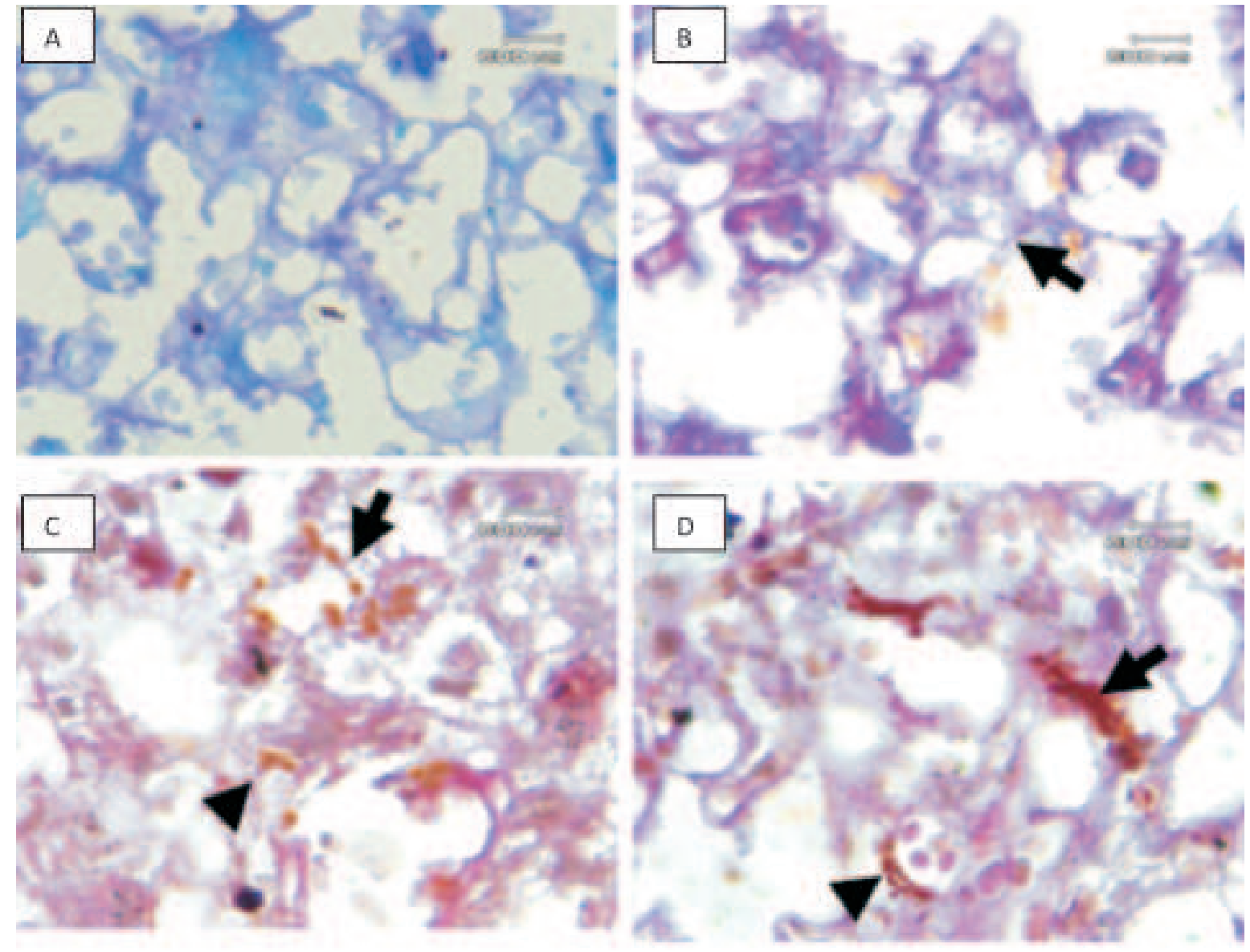

Gambar 1. Ekspresi Vascular Endothel Growth Factor ditunjukkan oleh warna kekuningan hingga coklat tua pada sel-sel immunoreaktif. Pada slide A tidak nampak adanya sel immunoreaktif intensitas warna(skor 0). Pada slide B, ekspresi VEGF dengan intensitas lemah yang ditunjukkan dengan warna kuning kecoklatan (skor 1). Slide C menunjukkan sel immunoreaktif dengan intensitas sedang (skor 2). Slide D menunjukkan sel immunoreaktif dengan intesitas kuat dengan warna coklat tua (skor 3). Pada slide tersebut teramatinampak bahwa VEGF diekspresikan oleh sel cytotropoblast dan sel endotel (kepala panah) (Pewarnaan immunohistokimia ; pembesaran 1000 kali)

menunjukkan hasil yang signifikan. Hal tersebut menunjukkan bahwa dengan waktu kebuntingan yang sama dan peningkatan dosis carbon black dapat meningkatkan taraf signifikansi ekspresi VEGF, menunjukkan dosis berpengaruh terhadap ekspresi VEGF pada dosis $532 \mathrm{mg} / \mathrm{m}^{3}$ dan $1064 \mathrm{mg} / \mathrm{m}^{3}$.

Carbon black merupakan bagian dari PM yang mengadung unsur karbon. Carbon black adalah salah satu produk kimia yang paling stabil di udara. Secara umum, carbon black merupakan nanomaterial yang paling banyak digunakan dan agregat dimensi yang berkisar dari puluhan hingga beberapa ratus nanometer (Jefrey dan Edison, 2013). Carbon black termasuk kedalam komponen PM yang bersifat sitotoksik dan genotoksik.
Carbon black diketahui dapat berpengaruh terhadap fetus melalui beberapa mekanisme di antaranya secara langsung masuk kedalam plasenta, sehingga menyebabkan perubahan fungsi pada plasenta dan secara tidak langsung memengaruhi perubahan sitokin yang ada di plasenta (Hougraad et al., 2011). Masuknya carbon black kedalam tubuh melalui proses pernafasan dan mengikuti aliran darah, menyebar kedalam organ-organ tubuh secara tidak langsung.

Respons inflamasi yang terjadi di semua organ termasuk pada plasenta memicu dihasilkannya berbagai sitokin hasil peradangan dan jumlahnya meningkat, masuk kedalam plasenta melalui aliran darah beserta partikulatnya. Semakin kecil ukuran 
Tabel 2. Ekspresi sel imunoreaktif vascular endothel growth factor pada plasenta

\begin{tabular}{lllll}
\hline Perlakuan & & $\begin{array}{l}\text { SkorPersentase } \\
\text { Positif(A) }\end{array}$ & $\begin{array}{l}\text { SkorIntensitas } \\
\text { Warna(B) }\end{array}$ & $\begin{array}{l}\text { Indeks } \\
\text { IRS(AX B) }\end{array}$ \\
\hline II-K0 & IIK0-1 & 0 & 0 & 0 \\
Kontrol tanpa paparan & IIK0-2 & 1 & 2 & 2 \\
pada kebuntingan 6-11 hari & IIK0-3 & 0 & 0 & 0 \\
& IIK0-4 & 0 & 0 & 0 \\
& IIK0-5 & 0 & 0 & 0 \\
\hline II-K1 & IIK1-1 & 1 & 3 & 3 \\
paparan carbon black 534 mg/m ${ }^{3}$ & IIK1-2 & 1 & 3 & 3 \\
pada kebuntingan 6-11 hari & IIK1-3 & 1 & 2 & 2 \\
selama 8 jam & IIK1-4 & 1 & 2 & 2 \\
& IIK1-5 & 1 & 2 & 2 \\
\hline II-K2 & IIK2-1 & 1 & 3 & 3 \\
paparan carbon black 1064 mg/m & IIK2-2 & 1 & 3 & 3 \\
pada kebuntingan 6-11 hari & IIK2-3 & 1 & 3 & 3 \\
selama 8 jam & IIK2-4 & 2 & 3 & 6 \\
& IIK2-5 & 2 & 3 & 6 \\
\hline
\end{tabular}

Keterangan: Semua perlakuan diuji dengan Uji Kruskal Wallis dan didapatkan hasil yang berbeda nyata $(\mathrm{p}<0,05)$ kemudian dilanjutkan dengan Uji Mann Whitney antar 2 perlakuan masingmasing.IRS : Indeks Skala Remele

Tabel. 3. Hasil Uji Mann Whitney hasil ekspresi vascular endothel growth factor

\begin{tabular}{llll}
\hline Imunohistokimia Vegf & Kelompok & Perlakuan & Sig \\
\hline II K0 & II K1 &, $014^{*}$ \\
& II K2 &, $006^{*}$ \\
& III K0 &, 881 \\
& II K1 & III K1 &, $006^{*}$ \\
& III K2 &, $006^{*}$ \\
\hline
\end{tabular}

*Signifikan $\mathrm{p}<0,05$

Ket.

II K0 : Kontrol tanpa carbon black paparan pada kebuntingan 6-11

II K1 : Paparan carbon black $534 \mathrm{mg} / \mathrm{m}^{3}$ pada kebuntingan $6-11$ selama 8 jam

II K2 : Paparan carbon black $1064 \mathrm{mg} / \mathrm{m}^{3}$ pada kebuntingan 6-11 selama 8 jam

III K0: Kontrol tanpa carbon black paparan pada kebuntingan 6-17

IIIK1 : Paparan carbon black $534 \mathrm{mg} / \mathrm{m}^{3}$ pada kebuntingan $6-17$ selama 8 jam

IIIK2 : Paparan carbon black $1064 \mathrm{mg} / \mathrm{m}^{3}$ pada kebuntingan 6-17 selama 8 jam

nanopartikel maka sitokin dan respons infllamasi akan semakin banyak dan jumlah distribusi melalui pembuluh darah makin luas (IRSST, 2008). Akibat dari respons inflamasi yang mensekresi sitokin-sitokin serta partikulat beserta radikal hidroksil yang dibawa oleh darah pada plasenta memengaruhi permeabilitas membran sel. Hal tersebut dapat menyebabkan peningkatkan kekentalan darah yang mengakibatkan penurunan suplai oksigen pada fetus. Jika suplai oksigen transplasenta terganggu dapat mengakibatkan hipoksia pada fetus.

Akibat stres karena terpapar carbon black akan menyebabkan perubahan sitokin pada plasenta sehingga akan memengaruhi respons selular, peradangan, gangguan jaringan homeostasis, dan akan berpengaruh terhadap 
sistem pembuluh darah plasenta. Sel pembuluh darah endothel dalam plasenta akan mengalami gangguan, dan mendorong terjadinya peradangan. Perubahan sitokin yang ada akan memicu perubahan patologis seperti angiogenesis, vaskular homeostasis, dan keadaan iskhemik (Monique, 2001).

Senyawa VEGF bertindak sebagai sitokin pro-inflamasi dengan meningkatkan permeabilitas sel endotel, merangsang ekspresi endotel adhesi molekul, dan memiliki kemampuan untuk bertindak sebagai monosit chemoattractant. Senyawa VEGF sangat banyak diekspresikan oleh sel epidermal keratinosit untuk penyembuhan luka dan psoriasis, ditandai dengan peningkatan permeabilitas mikrovaskuler dan angiogenesis.

Salah satu sitokin yang berpengaruh dalam pembentukan pembuluh darah baru adalah VEGF. Ekspresi VEGF dipengaruhi oleh kondisi hipoksia dan ekspresi sitokin lain (Levy et al., 1995; Dvorak et al., 1995). Peningkatan tumor nekrosis faktor (TNF) akan meningkatkan produksi VEGF sehingga dapat meningkatkan regulasi oleh sinyal membran sel dan sel mononuklear darah tepi dari rheumatoid arthritis (Bottomley et al., 2000).

Dari hasil penelitian, paparan carbon black $523 \mathrm{mg} / \mathrm{m}^{3}$ dan $1064 \mathrm{mg} / \mathrm{m}^{3}$ pada umur kebuntingan yang sama yaitu kebuntingan minggu ke-2 dibandingkan dengan kontrol menunjukkan hasil yang berbeda secara signifikan. Demikian pula pada kebuntingan minggu ke-3 yaitu antar perlakuan kebuntingan 6-17 hari yang diberi paparan carbon black 523 $\mathrm{mg} / \mathrm{m}^{3}$ dan $1064 \mathrm{mg} / \mathrm{m}^{3}$ juga menunjukkan hasil yang secara signifikan berbeda jika dibandingkan dengan kontrol.

Hal tersebut mengindikasikan bahwa umur kebuntingan berpengaruh terhadap ekspresi VEGF. Pada perlakuan dengan paparan carbon black $523 \mathrm{mg} / \mathrm{m}^{3}$ dan dosis $1064 \mathrm{mg} / \mathrm{m}^{3}$ pada kebuntingan 6-11 hari terjadi peningkatan ekspresi VEGF yang signifikan. Demikian pula dengan paparan carbon black $523 \mathrm{mg} / \mathrm{m}^{3}$ dan dosis $1064 \mathrm{mg} / \mathrm{m}^{3}$ kebuntingan 6-17 hari menunjukkan hasil yang signifikan. Hal tersebut mengindikasikan bahwa paparan carbon black memberikan efek negatif terhadap proses kebuntingan dan perubahan yang ditimbulkan juga sangat tergantung pada dosis yang diberikan.
Ekspresi MAP Kinase pada Placsenta Tikus Bunting yang Dipapar Carbon Black Ekspresi MAPK pada setiap sampel dinilai secara semikuantitatif menurut metode Remmele yang sudah dimodifikasi (Novak et al., 2007). Indeks skala Remmele (IRS) merupakan hasil perkalian antara skor persentase sel immunoreaktif dengan skor intensitas warna yang dihasilkan pada sel (Tabel 1). Pengaruh paparan carbon black terhadap ekspresi MAPK plasenta melalui pewarnaan imunohistokimia berdasarkan umur kebuntingan dan dosis paparan, dihitung secara semikuantitatif, disajikan pada Tabel 4, 5, dan Gambar 2.

Carbon balck merupakan partikel dengan ukuran nanometer (nanopartikel) yang digolongkan pada ultrafine PM. Masuknya carbon black pada paru-paru dapat memicu respons inflamasi yang kuat pada paru-paru, terdeposit pada paru-paru, dan tereliminasi secara pelan-pelan. Translokasi nanopartikel dari paru-paru kedalam sirkulasi darah berjalan secara pelan dan terus menerus (Jacobsen et al., 2008). Inflamasi akut pada paru-paru akan memicu peningkatan sitokin proinflamasi. Banyaknya nanopartikel yang terdeposit pada paru-paru meningkatkan stress oksidatif, yang selanjutnya akan meningkatkan produksi ROS.

Paparan carbon black berpengaruh terhadap keadaan morfologi dan respons fisiologi pada plasenta tikus, terutama pada bagian labirin plasenta yaitu tempat bertemunya sirkulasi darah induk dan fetus. Adanya paparan hidrokarbon menyebabkan tingginya ROS pada sel plasenta termasuk pada pembuluh darah endotel. Tingginya kadar ROS menyebabkan nekrosis maupun apoptosis pada sel endotel tersebut. Kerusakan pembuluh darah memicu respons fisiologi untuk membuat pembuluh darah baru (angiogenesis).

Pada usia kebuntingan 6-11 hari termasuk dalam kebuntingan minggu ke-2, plasenta pada tikus telah terbentuk cukup sempurna dan telah terbentuk barrier plasenta. Barrier plasenta tersebut juga telah bekerja optimal menahan laju invasi benda asing dalam hal ini adalah carbon black yang masuk ke dalam plasenta melalui darah. Selain itu pada umur kebuntingan tersebut pada plasenta tikus memiliki sistem regenerasi pembuluh darah dan vaskularisasi yang baik. Sistem regenerasi vaskularisasi dari plasenta tikus difungsikan untuk menahan 
Tabel 4. Ekspresi sel imunoreaktif mitogen activating protein kinase pada plasenta

\begin{tabular}{lllll}
\hline Perlakuan & & $\begin{array}{l}\text { SkorPersentase } \\
\text { Positif(A) }\end{array}$ & $\begin{array}{l}\text { SkorIntensitas } \\
\text { Warna(B) }\end{array}$ & $\begin{array}{l}\text { Indeks IRS } \\
\text { (A X B) }\end{array}$ \\
\hline II-K0 & IIK0-1 & 0 & 0 & 0 \\
Kontrol tanpa paparan & IIK0-2 & 0 & 0 & 0 \\
pada kebuntingan 6-11 hari & IIK0-3 & 1 & 3 & 3 \\
& IIK0-4 & 0 & 0 & 0 \\
& IIK0-5 & 0 & 0 & 0 \\
\hline II-K1 & IIK1-1 & 2 & 2 & 4 \\
paparan carbon black 534 mg/m ${ }^{3}$ & IIK1-2 & 1 & 3 & 4 \\
pada kebuntingan 6-11 hari & IIK1-3 & 1 & 3 & 3 \\
selama 8 jam & IIK1-4 & 1 & 2 & 2 \\
& IIK1-5 & 1 & 3 & 3 \\
\hline II-K2 & IIK2-1 & 2 & 3 & 6 \\
paparan carbon black 1064 mg/m & IIK2-2 & 1 & 3 & 3 \\
pada kebuntingan 6-11 hari & IIK2-3 & 1 & 3 & 6 \\
selama 8 jam & IIK2-4 & 2 & 3 & \\
IIK2-5 & 1 & 3 & 3 & 3 \\
\hline
\end{tabular}

Keterangan : Semua perlakuan diuji dengan Uji Kruskal Wallis dan didapatkan hasil yang berbeda nyata $(p<0,05)$ kemudian dilanjutkan dengan Uji Mann Whitney antar 2 perlakuan masing-masing. IRS : Indeks Skala Remele

Tabel. 5. Hasil Uji Mann Whitney hasil ekspresi mitogen activating protein kinase

\begin{tabular}{llll}
\hline Imunohistokimia MAPK & Kelompok & Perlakuan & Sig \\
\hline \multirow{2}{*}{ II K0 } & II K1 &, $026^{*}$ \\
& & II K2 &, $014^{*}$ \\
& III K0 &, 606 \\
& III K1 &, $011^{*}$ \\
& II K1 & III K2 &, $008^{*}$ \\
& II K2 &, 238 \\
\hline
\end{tabular}

*Signifikan $\mathrm{p}<0,05$

Keterangan :

II K0 : Kontrol tanpa paparan pada kebuntingan 6-11

II K1 : Paparan carbon black $534 \mathrm{mg} / \mathrm{m}^{3}$ pada kebuntingan $6-11$ selama 8 jam

IIK2 : Paparan carbon black $1064 \mathrm{mg} / \mathrm{m}^{3}$ pada kebuntingan 6-11 selama 8 jam

III K0: Kontrol tanpa paparan pada kebuntingan 6-17

III K1 : Paparan carbon black $534 \mathrm{mg} / \mathrm{m}^{3}$ pada kebuntingan $6-17$ selama 8 jam

IIIK2 : Paparan carbon black $1064 \mathrm{mg} / \mathrm{m}^{3}$ pada kebuntingan 6-17 selama 8 jam

invasi inflamasi, karena tipe plasenta tikus memiliki percabangan yang sangat kompleks di daerah labirin plasenta. Hal tersebut dimaksudkan agar pertukaran nutrisi dari induk dan anak efisien.

Saat paparan carbon black masuk kedalam plasenta dan menimbulkan inflamasi di plasenta melalui sistem vaskularisasi maka respons fisiologi pada sel hofbauer adalah memfagositosis carbon black. Selain itu sel hofbauer mensekresi sitokin inflamasi VEGF yang memicu regenerasi vaskularisasi kembali pada kebuntingan minggu ke-2. Apoptosis sel-sel tropoblas plasenta semakin bertambah dengan adanya faktor inflamasi akibat carbon black yang masuk melalui pembuluh darah. Kondisi tersebut teramati pada ekspresi VEGF maupun MAPK dari sel-sel yang immunoreaktif dengan 

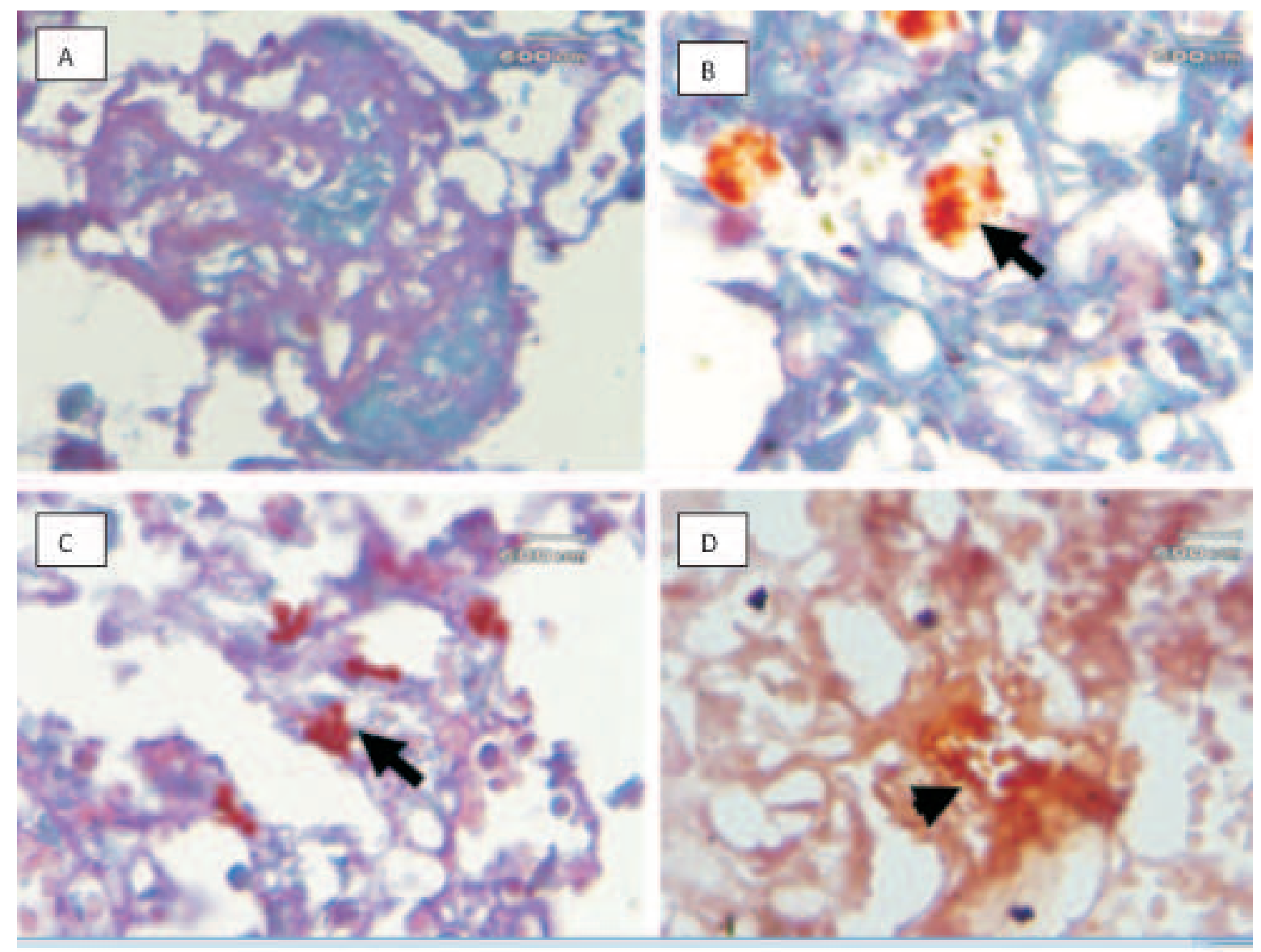

Gambar 2. Ekspresi Mitogen Activating Protein Kinase ditunjukkan oleh warna coklat muda hingga coklat tua pada sel-sel immunoreaktif. Pada slide A tidak nampak adanya sel immunoreaktif (skor 0). Slide B menunjukkan ekspresi MAPK dengan intensitas sedang yang ditemukan pada sel syntropoblast (panah) (skor 2). Slide C dan D menunjukkan sel immunoreaktif terhadap MAPK dengan intesitas kuat dengan warna coklat tua yang banyak diekspresikan oleh sel-sel cytotropoblast (panah) dan sel-sel endotel (kepala panah) (skor 3). (Pewarnaan immunohistokimia ; pembesaran 1000 kali).

intesitas kuat dengan warna coklat tua. Intensitas warna kuat tersebut diekspresikan baik oleh sel cytotropoblast dan sel endotel.

Dari hasil tersebut didapatkan perbandingan terhadap waktu kebuntingan yang sama antara kelompok tanpa paparan carbon black pada umur kebuntingan 6-11 hari selama delapan jam (II-KO) dengan kelompok perlakuan dengan paparan carbon black pada umur kebuntingan 6-11 hari selama delapan jam dengan dosis $534 \mathrm{mg} / \mathrm{m}^{3}$ ( II-KI) dengan menunjukkan hasil yang signifikan dan begitu pula dengan kelompok perlakuan dengan paparan carbon black pada umur kebuntingan 6-11 hari dengan dosis $1064 \mathrm{mg} / \mathrm{m}^{3}$ (II-K2) menunjukkan hasil yang signifikan.

Hal tersebut menunjukkan bahwa pada waktu kebuntingan yang sama dan peningkatan dosis carbon black dapat meningkatkan ekspresi MAPK secara signifikans. Hal tersebut menunjukkan dosis berpengaruh terhadap ekspresi MAPK, terutama pada dosis 1064 $\mathrm{mg} / \mathrm{m}^{3}$.

\section{SIMPULAN}

Terjadi peningkatan ekspresi VEGF dan MAPK pada plasenta tikus yang dipapar carbon black dosis $523 \mathrm{mg} / \mathrm{m}^{3}$ dan $1064 \mathrm{mg} / \mathrm{m}^{3}$ perinhalasi selama masa pertengahan (6-11 hari) kebuntingan. Ekspresi VEGF meningkat seiring dengan peningkatan dosis carbon black dan umur kebuntingan. 


\section{SARAN}

Paparan carbon black pada tikus bunting dapat meningkatkan kejadian inflamasi, oleh karena itu perlu diinformasikan bahwa kontaminasi carbon sangat berbahaya. Selain itu perlu dilakukan penelitian lanjutan untuk mengungkap mekanisme nekrosis oleh carbon black,sehingga kedepan bisa terjawab kaitan nekrosis dan apoptosis akibat carbon black pada tikus bunting

\section{UCAPAN TERIMAKASIH}

Terimakasih disampaikan pada Direktorat Pendidikan Tinggi melalui alokasi sumber dana Strategis Nasional yang telah mendanai penelitian ini.

\section{DAFTAR PUSTAKA}

Bottomley MJ, Webb NJ, Watson CJ, HoltL, Bukhari M,Denton J, Freemont AJ, Brenchley PE. 2000. Placenta growth factor (PlGF) induces vascular endothelial growth factor (VEGF) secretion from mononuclear cells and is co-expressed with VEGF in synovial fluid. Clin Exp Immunol 119: 82 188.

Dachlan EG, Widjiati, Budi S. 2011. Pengaruh Paparan Partikulat Jelaga Terhadap Peningkatan Lipid Peroksidase, Kejadian Apoptosis Plasenta Dan Luaran Kebuntingan Pada Mekanisme Molekuler Gangguan Kebuntingan Tikus (Rattus novergicus). Surabaya. Universitas Airlangga.

Dvorak HF, Brown LF, Detmar M, Dvorak, AM. 1995. Vascular permeability factor/vascular endothelial growth factor, microvascular hyperpermeability, and angiogenesis. Am J Pathol 146(5): 1029-39.

Debojyoti M, Ranjan B, Nilanjan S, Deepak P. 2010. A Note On Prevention And Control Of Sulfur Oxide Pollution. J Engineering Sci and Technlogy 2(8): 3926-3928

Dejmek JAN., Sherry GS, Ivan B, Ivo SY, Radim JS. 2013. Fetal Growth and Maternal
Exposure to Particulate Matter during Pregnancy. Environmental Health Perspectives 107 (6): 475-480

Hougaard KS, Fadeel B, Gulumian M, Kagan VE, Savolainen K. 2011.Developmental toxicity of engineered nanoparticles. In: Gupta RC, editor. Reprod Dev Toxic Hlm. 269-290

Institut de recherche en santeì et en seìcuriteì du travail(IRSST). 2008. Health Effects of Nanoparticles. Studies and Research Projects. REPORT R-589. 2nd edition.

Jackson P, Ull V, Håkan W, Karin SH. 2011. Maternal Exposure to Particulate Air Pollutionand Engineered Nanoparticles: Reproductive and Developmental Effects. $J$ Intech: 59-84.

Jacobsen NR, Pojana G, White P, Moller P, Cohn CA, Korsholm KS, Vogel U, Marcomini A, Loft S, Wallin H. 2008. Genotoxicity, cytotoxicity, and reactive oxygen species induced by single-walled carbon nanotubes and $\mathrm{C}(60)$ fullerenes in the FE1-Mutatrade mark Mouse lung epithelial cells. J Environ Mol Mutagen 49: 476-487.

Jefrey P, Edison M. 2013. Beneficiation of Pyrolitic Carbon Black.J. Chemical, Molecular, Nuclear, Materials and Metallurgical Engineering 7(10): 733-737

Levy, AP, Levy, NS, Wegner, S, Goldberg, MA.1995.Transcriptional regulation of the rat vascular endothelial growth factor gene by hypoxia. J Biol Chem 270: 13333-13340.

Monique CA, Duyndam, Theresa MH, Dennis F, Herbert MP, Epie B. 2001. Induction of Vascular Endothelial Growth Factor Expressionand Hypoxia-inducible Factor 1á Protein by the OxidativeStressor Arsenite. Department of Medical Oncology, Vrije Universiteit Medical Centre, De Boelelaan 1117, Amsterdam 1081 HV, The Netherlands

Novak M, Madej JA, Dziegeil P. 2007 Intensity of Cox 2 expression inCell of Soft Tissue Fibrosarcomas in Dog As Related to Grade of Tumor malignation. Bull Vet inst Pulawy 51: $275-279$ 